\title{
DELAYED APOPLEXY (SPAETAPOPLEXIE) WITH THE REPORT OF A CASE ${ }^{1}$
}

\author{
By Alfred Reginald Allen, M.D.
}

OF PHiladelpHIA, PA.

LECTURER ON NEUROLOGICAL ELECTRO-THERAPEUTICS; INSTRUCTOR IN NEUROLOGY AND IN NEUROPATHOLOGY IN THE UNIVERSITY OF PENNSYLVANIA; ASSISTANT NEUROLOGIST TO THE PHILADELPHIA GENERAL HOSPITAL; ASSISTANT ALIENIST TO THE ORTHOPEDIC HOSPITAL

(From the Department of Neurology and Laboratory of Neuropathology of the University of Pennsylvania.)

In I878 Duret ( 1 ) published his great work, "Etudes expérimentales et clinique sur les traumatismes cérébraux," founded upon seventy-one experiments on the lower animals, many of which are irrelevant to the subject at hand. The first chapter deals with twenty-five experiments, mostly on dogs, in which the cranium was subjected to one or more blows, or in which wax or some other substance was injected into the cranial cavity through a small trephine opening, in this way producing a cerebral compression. The future effect of this work was so farreaching that it seems to me advisable to quote a pertinent part of his conclusions: "Au moment d'une chute sur la tête, ou par un coup sur le crâne, un flot de liquide est formé autour des hémisphères et dans les ventricules, qui répercute la violence subie en un point, dans toutes les régions des centres nerveus, et plus particulièrement au niveau du bulbe rachidien.

"L'action vulnérante du flot aqueux exerce ordinairement ses effets les plus graves et les plus étendus, dans les lacs arachnoïdiens de la base du cerveau, autour du collet du bulbe, et principalement au niveau du plancher bulbaire, et sur les corps restiformes." [Translation: "At the moment of a fall on the head or a blow on the cranium a flow of liquid is formed about the hemispheres and in the ventricles which reflects the violence

${ }^{1}$ Read at the thirty-fourth annual meeting of the American Neurological Association, May 20, 2I and 22, 1908. 
sustained at one point, in all the regions of the nervous centers, and more particularly at the level of the medulla oblongata.

"The damaging action of the aqueous flow ordinarily exercises its most grave and extended effects in the arachnoidal spaces at the base of the brain, about the collet of the medulla and particularly at the level of the floor of the ventricle and on the restiform bodies."]

Although many times there was shown at autopsy a damaged or hemorrhagic condition of the floor of the fourth ventricle, there were nevertheless other considerable lesions in the brain well removed from the locality. This work of Duret's was followed in I 880 by an article by Gussenbauer (2) in the main confirmatory in tone of Duret's conclusions. He gives a résumé of theories held prior to Duret's experiments which is interesting historically. For three years he conducted experiments on the heads of cadavers in order to arrive at some conclusion as to the mechanics of concussion of the brain. To this end he mare a number of trephine holes in the skull, all in one direction, and then introduced deeply into the brain. substance pieces of straw, sticks of wood and long Karlsbad insect needles. $\mathrm{He}$ found that when he struck the head in the direction of the trephine openings there was a movement in the brain substance of the introduced bodies, but when the direction of force was not in the long axis or axis of insertion of those bodies, they remained stationary. Now experiments of this kind fail to reproduce the physical hypothesis of the living animal, on account of the changes in tissue after death. Moreover, these three years were spent in proving what is so obvious that it is practically an axiom, $i$. e., it is easier for a body to move through a medium in the direction of its long rather than its short axis, or to use a simile, a boat makes easier headway if it go either forward or backward than if it move sideways.

In speaking of general convulsions immediately following a trauma to the head, as in Duret's experiments, he says: "Sie sind die Folge der mechanischen Reizung, welche der durch die äussere Massenbewegung hervorgerufene Strom in der cerebrospinal Flüssigkeit am Boden des 4 Ventrikels, insbesondere aber in den sensiblen Corporibus restiformis bewirkt." [Translation: "They are the result of the mechanical irritation, which the stream of cerebrospinal fluid, caused by the external massive 
impulse, works on the floor of the fourth ventricle, but particularly on the sensory restiform body."] How he reaches this conclusion he does not say and I fail to see. Another statement which is hardly borne out in cases of lesions of the floor of the fourth ventricle in man is: "Langere Zeit andauernde Muskelcontractionen in dieser ersten Periode der Erscheinungen, deuten nach den Untersuchungen Duret's durchwegs auf erheblichere Verletzungen am Boden des 4 Ventrikels." [Translation: "Persistent muscular contractures in this first period of the symptoms point, according to Duret, to important injury to the floor of the fourth ventricle."]

In discussing unconsciousness in trauma to the head Gussenbauer holds that at the time of and immediately following the injury there is a decrease in pressure in the veins and an increase of pressure in the arteries, possibly due to general arterial contraction. This condition produces a temporary anemia, which in turn leads to unconsciousness. As soon as the circulation is restored to normal, consciousness returns. In severe cases there follows a reflex arterial paralysis which leads to venous stasis. This can lead to a second loss of consciousness. The reason for dealing with these views of Gussenbauer will be more apparent later on.

In I89I Bollinger (3) advanced his great hypothesis on late apoplexy. This was received by all practically without dissent, and so closely is his name identified with this reasoning from cause to effect that one frequently meets the term Spätapoplexie Bollingers. In his article he cites four cases, all the subjects of injury to the head. After a latent period, during which symptoms were either absent or inconspicuous, the late apoplexy came on. Bollinger's hypothesis is summed up as follows: First, a trauma to the head; second, a degeneration, particularly necrotic softening, in the cerebrum, pons or medulla; third, an alteration of blood vessels secondary to the necrotic softening; finally, the apoplexy due to three factors: (a) alteration in the vessels, $(b)$ the weakening of the tissue immediately surrounding the vessels, thereby decreasing their resistance to internal pressure, and (c) the raising of arterial pressure.

For twelve years Bollinger's views won nothing but acceptance and approbation.

In I903 Langerhans (4) published his monograph. This 
revolutionary work, a most brilliant critique, might be said to have for its text the following, which I quote: "Da Bollinger der geistige Vater der traumatischen Spätapoplexie ist, so lege ich damit gleichsam die Axt an die Wurzel der ganzen Lehre und setze mich in Gegensatz zu der allgemein herrschenden Anschauung." [Translation: "Because Bollinger is the spiritual father of the Traumatic Spätapoplexie, therefore I lay at once the axe to the root of the entire doctrine and set myself in opposition to the generally prevailing opinion."]

He first takes issue with Bollinger on account of the title of his paper: "Ein Beitrag zur Lehre von der Hirnerschütterung." He calls attention to the fact that Bollinger bases his arguments on Duret's experiments, in which, after blows on the head, there were found small punctiform hemorrhages in the aqueduct and immediate vicinity situated just beneath the ependyma, frequently the ependyma being torn. Bollinger thought that he had bridged the gap between these experimental findings of Duret's and concussion of the brain. Langerhans says, in the first place, Bollinger's cases failed to show the symptoms of concussion. Moreover as concussion does not necessarily entail the changes in the aqueduct above mentioned, and as these changes are by no means constant in their connection with the symptom complex, therefore one must come to the conclusion that these changes are collateral in nature only, and in no sense form the anatomical basis of concussion. For these reasons Langerhans very properly concludes that Bollinger's title is a misstatement.

In dealing with Bollinger's cases Langerhans' criticisms are as follows: In Case I the fact that there was a considerable fracture of the skull with meningeal hemorrhage makes it extremely doubtful what part if any the lesions of the aqueduct played. This is particularly emphasized by the fact that the microscopical examination of the brain stem was meager in the extreme. In Case II there was found in the brain no alteration of the blood vessels, no area of softening and no traumatic degeneration to account for the hemorrhage. In Case III the injury must have been one and a half hours before death or else is merely supposititious; there was no alteration of blood vessels and no area of softening. In Case IV there was no Spätapoplexie and no microscopical examination of the isthmus. There was, however, an area of softening in the isthmus. 
The utter demolition of Bollinger's views is so complete that Langerhans' simile, "die Axt an die Wurzel," is well taken. How it has been possible for the medical fraternity, usually so exacting in their demands when anything new is advanced, to accept without question these utterly fallacious lines of reasoning, the glaringly inadequate data; how it has been possible for twelve years to pass before the man comes forward to fairly riddle the preposterous structure of pseudo-reason, are things which must ever remain wonderful and inexplicable in the history of medicine.

Langerhans' discussion of Seydel's (5) case is masterly. He comes to the conclusion that the patient did not suffer a traumatic late apoplexy (Spätapoplexie Bollingers), but that on account of the hypertrophied heart and the arterial condition, miliary aneurismata most likely being present, the injury to the head was enough to cause an increase of blood pressure sufficient in force to burst one of the lenticulo-striate arteries.

From a study of the case of Maurermeister Lorenz Gerbl (6), which Bollinger thought one of Spätapoplexie, Langerhans draws the following conclusions: " ( $\mathrm{r}$ ) L. G. an spontaner Himblutung gestorben ist; (2) ein Zusammenhang der Hirnblutung des L. G. mit dem Hinfallen, dem angeblichen Unfall nicht bewiesen und auch nicht wahrscheinlich ist." [Translation: "(I) L. G. died from spontaneous hemorrhage into the brain; (2) a connection between the hemorrhage into the brain and the fall, the alleged accident, is not proven and also not likely."] These statements seem altogether too strong to me. When one suffers from an apoplexy, the immediate cause of the broken artery being an increased blood pressure, and the increased blood pressure having been preceded by such an accident as L. G. suffered, it is questionable whether the term "spontaner" can be used with accuracy. Also the microscopical examination of the brain was such that miliary aneurism cannot be excluded and therefore I think Langerhans' second conclusion too strongly stated.

In I903 also appeared the work of Stadelmann (7). This paper is particularly valuable on account of three conditions which he advances, coincidence with which he holds as necessary to the correct diagnosis of late apoplexy. They are important enough to quote verbatim. " (I) Der betreffende Kranke muss. nachweislich vorher gesund gewesen sein, keine Zeichen von Gefäss- 
veranderungen dargeboten haben, Lues, Nephritis, Potus, Herzerkrankungen müssen ausgeschlossen sein, auch darf es sich nicht un ältere Leute handeln, die sowie so schon an arteriosklerose leiden können, resp. bei denen sie sich spontan entwickeln kann. (2) Das Trauma muss erheblicher gewesen sein, wenn es auch nicht nöthig zu sein scheint, dass es direkt zur Bewusstlosigkeit geführt hat. (3) Die Erscheinungen der Gefasserkrankungen, resp. der weiteren Gehirnerkrankung müssen sich in kürzerem Zeitraume und unter unseren Augen entwickelt haben. Liegen erst Jahre dazwischen, in denen die ärztliche Beobachtung fehlt, so werde ich mich nie entschliessen können, ein irgendwie bestimmtes Urtheil über den Zussammenhang des Trauma mit den jetzt zu beobachtenden Erscheinungen abzugeben." [Translation: "( $\mathrm{r}$ ) The patient concerned must without question have been in good health, no signs of alteration in blood vessels having existed, syphilis, nephritis, alcohol and heart disease must have been excluded; also old people who so frequently suffer from arteriosclerosis cannot be considered; in other words, those who can develop it (apoplexy) spontaneously.

"(2) The injury must have been considerable, although it does not seem necessary that it should have caused unconsciousness.

"(3) The symptoms of the vascular or brain lesion must have developed within a short space of time and under our own eyes. If years have intervened in which there has been no medical surveillance I cannot determine with any kind of precise judgment a relationship between the trauma and the symptoms now appearing."]

According to Stadelmann, the development of a late apoplexy is as follows: (a) Disturbance of circulation; $(b)$ softening, and (c) late hemorrhage in the softened area of the brain.

Inferences drawn from cases such as presented by Bohne (8), Wimmer (9), and Rupp (ro), in which the patients did not come to necropsy, are all of doubtful value.

Kurt Mendel (Ir) divides cases of traumatic late apoplexy into two classes: Class A, those cases in which the vessel in question is the seat of an arteriosclerotic process at the time of injury; Class $B$, those cases in which the trauma catses a disease of the wall of a blood vessel, previously normal.

(ad A.) The trauma either causes an immediate rise in blood pressure, in which case we have a traumatic apoplexy, or it causes 
an increase in blood pressure which takes place some time afterward, this leading to the late apoplexy. He says that any trauma, even though it does not directly affect the skull, can cause an hyperemia of the brain. Also an emotional shock, such as sudden fear, can cause a vasomotor disturbance with increased blood pressure.

(ad B.) $\mathrm{He}$ advances the following theories:

I. On account of softening in surrounding tissue the vessel dilates and its walls become thin.

2. The vessel wall takes part in the concussion and suffers from fatty degeneration.

3. Miliary aneurisms are formed on account of changes in the walls of blood vessels.

4. A disturbance in the nutrition of the walls of the blood vessels secondary to circulatory disturbance with consequent formation of aneurisms.

5. A certain relation exists between accident (trauma) and arteriosclerosis, especially of the vessels of the brain and spinal cord.

Kurt Mendel has watched the development of arteriosclerosis after trauma. He has seen patients who have suffered a traumatism of one side in which headache has been confined to the injured side and in which the temporal artery of that side has become tortuous and hard. His final conclusions are that whereas the clinical history shows a clear relation between trauma and late apoplexy, pathology has, up to the present, failed to do so. $\mathrm{He}$ thinks that the cases in which late apoplexy are caused solely by trauma without any preëxisting arterial degeneration are exceedingly rare.

Late apoplexy is found in literature according to Kurt Mendel in patients from seven to seventy years of age. The latent period, the time elapsing between the injury and the apoplectiform seizure, can vary from four days to nine months. Usually this latent period is from one to six weeks and can be absolutely free from symptoms or show mild mental hebetude and some headache.

I am indebted to Dr. William G. Spiller for the history and pathological material of the following case:

Annie M., white, female, aged 36 years, occupation, cook ; presents the following history: Father is living and well; mother is dead, cause unknown. Two sisters and one brother living and 
well. No brothers or sisters dead. No history of tuberculosis or malignant disease. Her family were of nervous and excitable temperament. The history of diseases of childhood could not be elicited. There is a history of influenza sixteen years ago, also anemia when a child. Fourteen years ago she was operated upon for some uterine trouble the exact nature of which is not known. She has had four children, the youngest of whom is ten months old. One child died of diphtheria. No miscarriage and labors normal. Two years ago she became suddenly violently insane and had to be confined in an institution for three months, at the expiration of which time she had recovered sufficiently to be discharged. Her husband states that she frequently complained of nervous headaches, although her general health had been good. She never used alcohol immoderately. All venereal history was denied.

On February 27, 1907, the patient had a quarrel with a neighbor and was struck repeatedly, ten or fifteen times, over the head and face with the fist. From this time she began complaining of severe headache which was not localized. Ten days after the quarrel, while she was lying down with her baby, her husband heard a sound as if something had fallen and found that she had dropped her baby to the floor and was lying with the right arm and leg completely paralyzed and was motor aphasic. She was not unconscious and had lost control of her bladder and rectum.

She was admitted to the hospital March I2, I907, in a semistuporous condition. The one word she was able to say was "No." There is a history of cough, expectoration and pain in her chest between the time of her injury and her apoplectiform seizure and her family physician said in this time she had pleurisy and probably pneumonia.

As she was completely motor aphasic except for the single word "No," and as she used this word in answer to every question, it was hard to determine whether she was word deaf, but the chances are that she was not; if asked whether her name was Annie she would say "No." On two occasions she gave her left hand when asked, but it was impossible to get her to do anything else. She had a right facial paralysis of central type. She opened and closed both eyes firmly and equally. It was impossible for her to protrude her tongue but it deviated to the left while in the mouth. The biceps and triceps reflex were not very distinct on the left side, but were much more distinct on the right. Pin prick caused pain over the entire right side. Once or twice the Babinski reflex seemed to be obtained on the right, but it was not constant. Patellar tendon and Achilles tendon reflexes were present and equal on each side.

On March ${ }_{5}$ it is recorded that "her lungs were full of fluid and her pulse extremely rapid."

The patient died on March I8, at 8 A. M. 
Sections of the spinal cord at the level of the fourth lumbar and fourth thoracic segments were stained by the Weigert hematoxylin, hemalum-acid fuchsin and von Lenhossék-Nissl methods, and showed no pathological alteration. The amount of central glia substance in the fourth lumbar segment was much greater than is usually seen. An examination of sections in the midolivary region showed that the ependymal lining of the fourth ventricle was, at this level, in perfect condition. Many of the blood vessels in the sections from the mid-olivary level presented a lumen packed with erythrocytes. The perivascular lymph spaces were greatly distended and filled with an unstaining detritus which in several instances could be seen to contain erythrocytes, but by far the largest part of this detritus was albuminous coagulum. In several instances the point of escape from the vessel of the erythrocytes could be detected. This condition of affairs was not limited to the immediate subependymal part of the floor of the fourth ventricle, but is also seen far anterior to this, one such vessel being located in the hilus of one of the inferior olives. In this latter case blood pigment was found in the detritus filling the lymph space. A section at the level of the decussation of the fourth cranial nerves showed a few of these distended vessels in the neighborhood of the aqueduct. But the chief point of interest here is an area anterior to the decussation of the superior cerebellar peduncles. This area is located in the mid-line and shows several large blood vessels with the surrounding unstained detritus and in addition a pronounced hemorrhagic condition. This lesion is easily seen with the unaided eye and measures approximately two millimeters transversely by one millimeter antero-posteriorly. The ependymal lining of the aqueduct at this level is unaltered. A section through the cerebral peduncles at the level of the mammillary bodies and the middle of the red nuclei shows a slight tearing at one point of the ependymal lining of the aqueduct and also a microscopical hemorrhage into the ependymal lining at another point. Here, as in sections lower down, one finds the distended perivascular lymph spaces but not in so great numbers. A section through the optic chiasm and anterior part of the optic tract shows many erythrocytes free in the ependymal lining of the third ventricle. The chiasm, optic nerve and optic tracts are normal.

In the left lenticular region sections were made from blocks of tissue, the highest level of which corresponded to a plane passing just above the highest part of the lenticular nuclets. Over four hundred and fifty sections were made, the lowest plane being reached when the middle cerebral artery was cut longitudinally. Sections were stained at different levels of the series by means of the Weigert hematoxylin, Van Gieson's, Weigert's elastica and hemalum-acid fuchsin methods.

The lowest sections, those having the middle cerebral artery 
cut longitudinally, show the small vessels filled with blood. In some instances there is a tearing of the intima and media with a passage of erythrocytes into the perivascular lymph spaces. In some of the small vessels there is thrombus formation and the presence of fatty granular cells about the vessels. As successive levels higher up are examined, the occluded vessels are of more frequent occurrence and are located chiefly in the globus pallidus and putamen of the lenticular nucleus. There are found also a few occluded vessels in the optic thalamus. At about the midlevel of the lenticula there is found in the globus pallidus a vessel, the muscular portion of whose wall shows calcification. This is the only vessel which I have examined in this case which showed this process. Within the lumen there is seen an hyperplasia of the endothelial lining. At about the mid-level of the lenticula there is found a process of softening which is chiefly confined, at this level, to the globus pallidus and in which are frequently seen fatty granular cells. At the highest level of the lenticula the area of softening has greatly increased and extends well through the white matter external to the caudate nucleus and optic thalamus for a distance antero-posteriorly of about five centimeters. There are also small areas of softening in the caudate nucleus.

Sections of the right and left paracentral lobules were stained by the von Lenhossék-Nissl method. The large motor cells of the right side were normal but those of the left side showed marked degenerative reaction.

Among other things the general post-mortem notes state that the cortical epithelium of the kidney presents a moderate degree of cloudy swelling. There was some general kidney congestion and a slight increase of connective tissue between the tubules was noted. There seems to be no evidence from the histological examination of undue arterial change.

Cases of this kind are particularly interesting from a medicolegal standpoint. There are so many instances on record of trauma to the head followed after a greater or less time by late apoplexy that we may be morally certain that a definite relation between trauma to the head and the apoplectiform seizure does exist. But are we in possession of every link in the chain of pathological circumstances so that we can swear on the witness stand that a given case of apoplexy is a late apoplexy due to the trauma? This question must be answered unqualifiedly in the negative.

My conclusions, drawn from the above case, together with the many on record, must of necessity be theoretical and are as follows:

(a) Traumatic delayed apoplexy (Spätapoplexie), in the sense of the original Greek, $\dot{a} \pi \sigma \pi \lambda \eta^{\prime} \sigma \sigma \epsilon \omega v$, is in all probability, an entity. 
(b) Delayed apoplexy is not of necessity a condition in which hemorrhage takes place, but the stroke can have as its immediate etiological factor the occluding or thrombosis of one or more arteries.

(c) The cerebro-spinal fluid does not play a necessary part in the production of delayed apoplexy and injury to the region of the aqueduct and fourth ventricle is a collateral circumstance of no etiological moment.

(d) In cases of delayed apoplexy in which hemorrhage takes place, the hemorrhage is not necessarily preceded by a process of necrotic softening about the artery in question, this removing the outside support (Widerstandsfähigkeit) but the artery itself is injured as Langerhans holds, and the secondary rise in arterial pressure, or the normal pressure causes the hemorrhage.

(e) The mechanics of many cases of delayed apoplexy is as follows: The trauma to the head causes a mechanical agitation to the brain substance, which falls with greatest severity on the arteries, small and large, they being filled with an incompressible fluid. The particular location of the chief action on the vessels cannot be determined by the external impact of the blow or the direction of the force and is impossible of determination until revealed by symptomatology. At first there is in all probability a general vasomotor constriction of the cerebral arterial system followed very shortly by a paresis of the vessel walls. The vessels particularly injured undergo endothelial proliferation, and thrombotic processes are set up. Then occlusion, if in a functionally important area of the brain, can cause an apoplectic attack. To this class belongs my case.

In considering a case of what may be traumatic delayed apoplexy, a possible incompetence on the part of the kidney must be borne in mind and the action of a consequent uremia must be given full weight. The case I report had a slight amount of chronic interstitial nephritis and had she not come to necropsy one could not have positively stated whether there was a hemorrhagic or thrombotic condition on the one hand, or a uremic attack. 


\section{BIBLIOGRAPHY}

I. Duret. “Etudes expérimentales et eliniques sur les traumatismes cérébraux," p. 153, Paris, 1878.

2. Gussenbauer. "Über den Mechanismus der Gehirnerschütterung," Prager med. Wochenschrift, I880, No. I-3.

-3. Bollinger. "Ueber traumatische Spätapoplexie," Internat. Beitr. zur wissenschaftl. Med. Virchow-Festschr., I89I, Bd. II.

4. Langerhans, R. "Die traumatische Spätapoplexie." Verl. v. A. Hirschwald, Berlin, I903.

5. Seydel. "Fall von traumatischer Spätapoplexie," Aerztl. Sachverst Ztg., I902, No. I8.

"6. Langerhans. Loc. cit., p. 50.

7. Stadelmann, E. "Üeber Späterkrankungen des Gehirns nach Schadeltraumen." Deutsche med. Wochenschr., I903, No. 6.

8. Bohne, Julius. "Ueber einen Fall von traumatischer Spätapoplexie." Fortschr. d. Med., I902, No. 36. No. $\stackrel{9}{8}$.

9. Wimmer. "Ueber traumatische Spätapoplexie." Med. Klinik, 1907, Io. Rupp. "Zur Kasuistik der traumatischen Spätapoplexie." Zeit. fur. Heilk., rgo5, Bd. XXVI.

II. Mendel, Kurt. "Der Unfall in der Atiologie der Nervenkrankheiten." Verl. von S. Karger, I908, pp. 48 to 6 I. 